\title{
Curahan Waktu Tenaga Kerja Keluarga Integrasi Sapi Bali dan Padi Sawah di Kecamatan Buke Kabupaten Konawe Selatan
}

\author{
La Ode Arsad Sani ${ }^{1}$, Musram Abadi ${ }^{2}$,Laode Muh. Munadi *3, La Ode Nafiu ${ }^{4}$, Rahmad Sawal ${ }^{5}$ \\ ${ }^{12345}$ Fakultas Peternakan Universitas Halu Oleo \\ Kampus Hijuau Bumi Tridharma, Kendari, Sulawesi Tenggara \\ Kode Pos: 93132 \\ Email:lmmunadi@gmail.com
}

\begin{abstract}
ABSTRAK
Penelitian ini bertujuan untuk mengetahui curahan waktu tenaga kerja keluarga pada usaha ternak sapi bali integrasi usahatani padi sawah di Kecamatan Buke Kabupaten Konawe Selatan. Lokasi penelitian ditentukan secara sengaja (purposive sampling) dengan pertimbangan wilayah Kecamatan Buke merupakan wilayah sentra pembibitan ternak sapi bali. Populasi penelitian dipilih sebanyak 6 desa berdasarkan jumlah populasi ternak terbanyak sekaligus terdapat lahan persawahan. Jumlah responden setiap desa dipilih 5 orang sehingga keseluruhan responden sebanyak 30 orang. Penentuan responden setiap desa terpilih dilakukan secara Simple Random Sampling. Hasil penelitian menunjukkan rata-rata curahan waktu tenaga kerja keluarga pada usaha ternak sapi Bali yaitu sebesar 0,94 HOK, sedangkan rata-rata curahan waktu tenaga kerja keluarga pada usahatani padi sawah yaitu sebesar 10,56 HOK. Secara umum tenaga kerja keluarga di Kecamatan Buke Kabupaten Konawe Selatan cukup tersedia namun lebih banyak mencurahkan waktunya pada usahatani padi sawah $(91,83 \%)$ dibandingkan usaha ternak sapi Bali $(8,17 \%)$.
\end{abstract}

Kata kunci: Sapi Bali, Padi sawah, Curahan waktu kerja

\begin{abstract}
This research aims to determine the availability and employment of the work time of family labor in bali cattle farming integration of rice field farming in the District Buke South Konawe District. The location of the research is determined intentionally (purposive sampling) in consideration of Buke subdistrict area is the area of cattle breeding center of bali. The research population will be selected 6 villages based on the number of livestock populations and there are rice fields. The number of respondents per village was 5 to the number of respondents as many as 30 respondents. The respondents determination of each selected village is done in Simple Random Sampling. The results of the study showed the average pouring time of family labor in the Bali cattle cattle business of $0,94 \mathrm{HOK}$, while the average pouring time of family labor in farm rice field is 10,56 HOK. In general, family Labor in Buke district South Konawe District is quite available but more devoted to rice farming $(91,83 \%)$ Compared to the Bali cattle farming $(8,17 \%)$.
\end{abstract}

Key words: Bali cow, Paddy fields, Working time 


\section{Pendahuluan}

Ternak sapi bali merupakan merupakan jenis ternak yang banyak dipelihara oleh masyarakat di Kecamatan Buke Kabupaten Konawe Selatan. Berdasarkan Surat Keputusan Kementerian Pertanian Nomor 803/Kpts/PK.030/12/2016 Kecamatan Buke ditetapkan sebagai wilayah sumber bibit sapi bali di Kabupaten Konawe Selatan. Ironisnya, kendatipun wilayah tersebut telah ditetapkan sebagai wilayah sumber bibit sapi bali, usaha ternak sapi bali masih dijadikan sebagai usaha sampingan.

Masyarakat di Kecamatan Buke pada umumnya memiliki pekerjaan utama mengelola usaha pertanian. Kondisi tersebut didukung oleh ketersediaan sumber daya alam dan kondisi geografis yang letaknya strategis, sehingga membuat wilayah ini memiliki peluang dalam pengembangan sektor pertanian. Potensi sumber daya yang dimiliki tersebut, membuka peluang bagi masyarakat untuk memanfaatkan sumberdaya yang tersedia dengan mengembangkan pengelolaan usaha ternak sapi bali dan usahatani padi sawah.

Usaha ternak sapi bali dan usahatani padi sawah memerlukan tenaga kerja sebagai salah satu unsur penentu optimasi keberhasilan usaha tersebut (Widhyawaty, 2019). Penggunaan tenaga kerja dalam usaha ternak sapi Bali dan padi sawah merupakan hal penting disamping modal dan manajemen usaha (Kusumayana \& Arlina, 2017). Pengelolaan usaha ternak sapi bali dan padi sawah di Kecamatan Buke pada umumnya didominasi oleh tenaga kerja keluarga. Kondisi tersebut merupakan fenomena yang umum terjadi dalam pengelolaan usaha pertanian pada wilayah pedesaan di Provinsi Sulawesi Tenggara.

Keterlibatan anggota keluarga pada suatu usaha dapat berpengaruh terhadap berjalannya usaha tersebut, terutama pada ketersediaan tenaga kerja (Sani et al., 2012). Analisa ketenagakerjaan pada usahaternak sapi bali dan usahatani padi sawah, dinyatakan oleh besarnya curahan jam kerja yang dipakai. Waktu bekerja yang dicurahkan untuk kegiatan-kegiatan tertentu di sektor pertanian maupun peternakan terhadap total waktu kerja angkatan kerja (Hitani et al., 2017).

Optimasi penggunaan tenaga kerja keluarga pada usaha ternak sapi bali dan usahatani padi sawah dipengaruhi oleh jumlah ternak yang dipelihara dan luas lahan padi sawah yang diolah serta pembagian waktu yang jelas antara usaha ternak sapi bali dan usahatani padi sawah (Hidayati et al., 2020). Curahan waktu kerja tergantung pada jenis pekerjaan yang dilakukan (Fyka et al., 2019). Tedapat kegiatan yang memerlukan curahan waktu yang banyak, tetapi sebaliknya ada pula jenis- kegiatan yang memerlukan curahan waktu kerja terbatas (Indrayani \& Andri, 2018).

Pengelolaan dua subsektor usahatani akan menyebabkan terjadinya persaingan atau pembagian tenaga kerja yang mungkin saja menyebabkan tidak efisien dalam pemakaiannya (Abadi et al., 2019). Hal ini menyebabkan penggunaan tenaga kerja dalam pengelolaan usaha ternak sapi bali merupakan pemanfaatan waktu senggang/kosong setelah petani menyelesaikan pekerjaannya pada usahatani utama. Oleh karena itu penelitian ini dilakukan dengan tujuan untuk menganalisis curahan waktu tenaga kerja keluarga integrasi sapi bali dan padi sawah di Kecamatan Buke Kabupaten Konawe Selatan.

\section{Materi dan Metode}

Penelitian ini dilaksanakan pada bulan Agustus sampai September 2020 di Kecamatan Buke Kabupaten Konawe Selatan. Penentuan lokasi dilakukan secara purposive sampling berdasarkan pertimbangan obyektif, bahwa Kecamatan Buke Kabupaten Konawe Selatan merupakan wilayah sentra pembibitan sapi bali. Pengambilan sampel penelitian dipilih sebanyak 6 desa berdasarkan jumlah populasi ternak terbanyak 


\section{Jurnal Sains Peternakan}

Volume 9 No. 1, Juni 2021, pp:1-6

ISSN 2579-4450

serta terdapat areal lahan persawahan. Jumlah responden untuk setiap desa berjumlah 5 orang sehingga jumlah keseluruhan sebanyak 30 orang. Penentuan responden setiap desa terpilih dilakukan secara Simple Random Sampling. Data yang akan dikumpulkan dalam penelitian ini terdiri atas data primer dan data sekunder. Pengumpulan data dilakukan dengan cara interview, observasi dan dokumentasi. Selanjutnya, data dianalisis sebagai berikut:

1. Curahan kerja laki-laki dewasa $=$ Jumlah jam kerja laki-laki $x$ JKSP

2. Curahan kerja perempuan dewasa $=$ Jumlah jam kerja perempuan $\mathrm{x}$ JKSP

3. Curahan kerja anak = Jumlah jam kerja anak x JKSP

Dimana : Jam kerja setara pria dewasa $(\mathrm{JKSP}=1), 1 \mathrm{JKSP} \quad$ untuk wanita $=0,8$ sedangkan untuk anak $=0,5$.

\section{Hasil dan Pembahasan}

\section{Curahan Waktu Kerja Tenaga Kerja Keluarga}

Teori alokasi waktu kerja didasarkan pada teori utilitas. Analisis mengenai curahan tenaga kerja merupakan analisis tentang penawaran tenaga kerja yang pada prinsipnya membahas keputusan anggota rumah tangga dalam pilihan jam kerjanya. Individu anggota rumah tangga dalam mengalokasikan jam kerjanya akan bertindak rasional, yaitu memaksimalkan utilitas. Curahan waktu kerja tergantung pada jenis pekerjaan yang dilakukan, ada jenis-jenis kegiatan yang memerlukan curahan waktu yang banyak dan kontinyu dan sebaliknya (Sani et al., 2012). Curahan waktu kerja tenaga kerja keluarga pada usaha ternak sapi Bali dan usahatani padi sawah di Kecamatan Buke Kabupaten Konawe Selatan disajikan pada Tabel 1.

Tabel 1. Curahan waktu kerja tenaga kerja keluarga pada usaha ternak sapi bali dan usahatani padi sawah di Kecamatan Buke Kabupaten Konawe Selatan

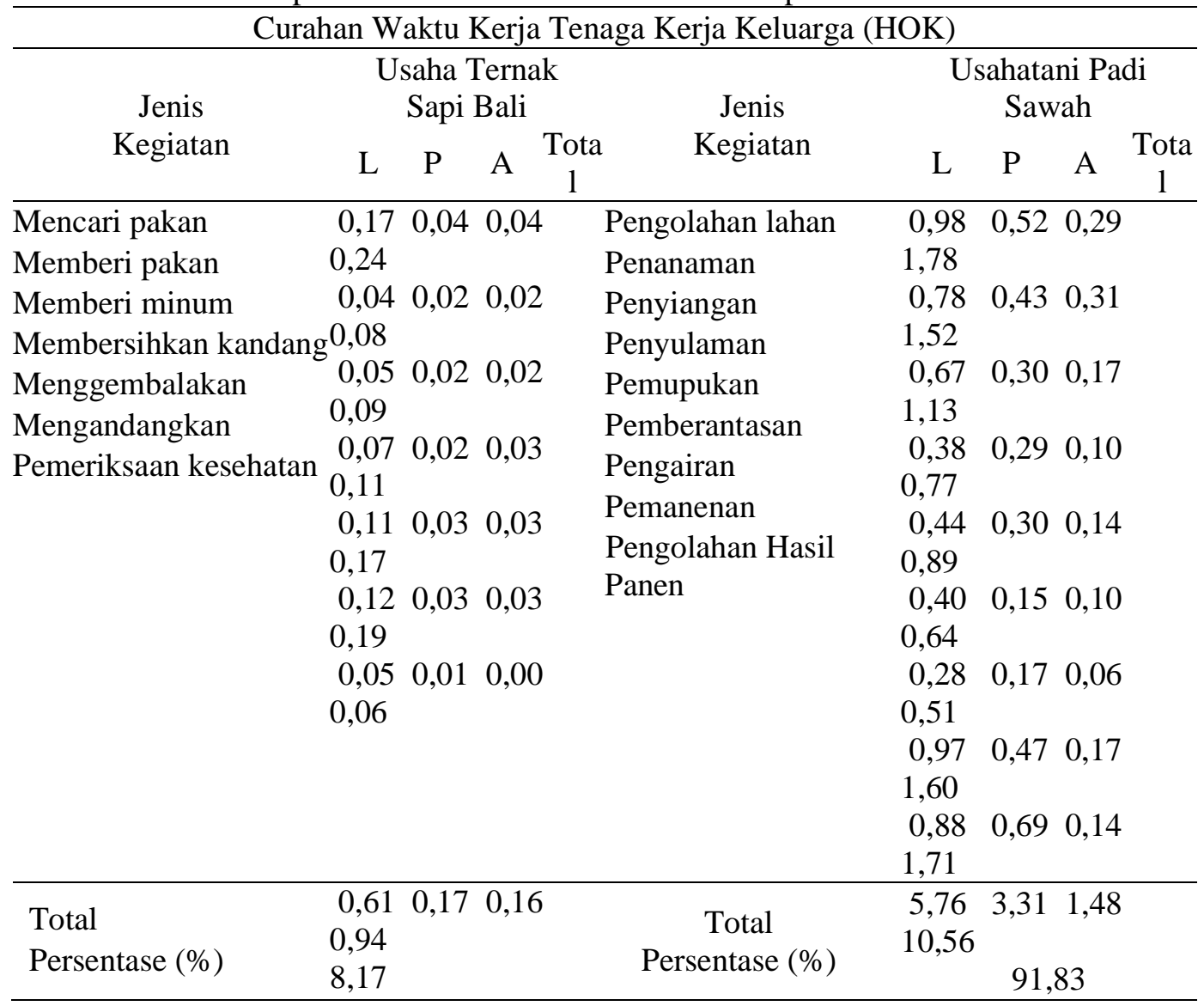




\section{Jurnal Sains Peternakan}

Volume 9 No. 1, Juni 2021, pp:1-6

ISSN 2579-4450

Sumber: data diolah, 2020.

Curahan waktu kerja tenaga kerja keluarga pada usahaternak sapi bali dan usahatani padi sawah lebih besar pada usaha tani padi sawah $(91,83 \%)$ dibandingkan usaha ternak sapi bali $(8,17 \%)$. Perbedaan curahan waktu kerja tersebut dipengaruhi oleh jumlah jenis kegiatan yang berbeda dan usahatani padi sawah merupakan usaha utama sedangkan usaha ternak sapi bali hanya sebagai usaha sampingan sehingga waktu yang dicurahkan pada usaha ternak sapi bali tidak begitu besar. Kondisi peternakan sapi bali di Kabupaten Konawe Selatan saat ini masih dalam skala usaha yang relatif kecil rata-rata 1-4 ekor. Usaha ternak sapi bali pada umumnya masih dianggap sebagai usaha sampingan, jauh dari penggunaan teknologi dan tidak dikelola dengan cukup baik (Abidin et al., 2018).

Curahan waktu kerja terbesar pada usahaternak sapi bali adalah kegiatan mencari pakan rata-rata 0,24 HOK dan terkecil adalah kegiatan pemeriksaan kesehatan sebesar 0,06 HOK. Pada usahatani padi sawah curahan waktu kerja terbesar adalah kegiatan pengolahan lahan $(1,78 \mathrm{HOK})$ dan terendah adalah kegiatan penyiangan $(0,13 \mathrm{HOK})$. Besarnya curahan waktu yang dibutuhkan dalam pengolahan lahan tersebut dipengaruhi oleh pengolahan yang harus dilakukan berkali-kali sekaligus disebabkan oleh luas lahan yang berbeda-beda.

Rata-rata curahan waktu kerja tenaga kerja keluarga pada usaha ternak sapi bali di Kecamatan Buke Kabupaten Konawe Selatan sebesar 0,94 HOK. Curahan waktu kerja tenaga kerja keluarga peternak sapi bali pada semua uraian kegiatan menunjukkan bahwa tenaga kerja keluarga peternak laki-laki membutuhkan waktu kerja yang lebih lama ratarata $0,61 \mathrm{HOK}$, tenaga kerja perempuan rata-rata $0,17 \mathrm{HOK}$ dan anak-anak rata-rata 0,16 HOK. Curahan jam kerja suami dalam usaha peternakan umumnya lebih tinggi dibandingkan jam kerja istri dan anak. Hal ini disebabkan karena istri lebih sibuk untuk mengurus rumah tangga dan mengasuh anak, sedangkan anak anak harus bersekolah. Norfahmi et al., (2017) mengatakan bahwa curahan tenaga kerja pria lebih tinggi dibandingkan dengan wanita, baik pada kegiatan pertanian maupun nonpertanian.

Curahan waktu kerja tenaga kerja keluarga pada usahatani padi sawah rata-rata 10,56 HOK. Curahan tenaga kerja tersebut sangat dipengaruhi oleh beberapa faktor seperti yang dikatakan oleh Simanjuntak et al., (2018) faktor tersebut berupa faktor alam seperti curah hujan, iklim, kesuburan, jenis tanah, dan topografi. Faktor jenis lahan yang meliputi sawah, tegal, dan pekarangan, serta luas, letak dan penyebarannya (Ningrum et al., 2019). Sehingga, faktor tersebut menyebabkan adanya perbedaan kesibukan tenaga kerja.

Curahan waktu tenaga kerja keluarga petani padi sawah pada semua jenis kegiatan di Kecamatan Buke menunjukkan bahwa curahan waktu kerja tenaga kerja keluarga petani padi sawah laki-laki membutuhkan waktu kerja yang lebih lama dengan jumlah 5,76 HOK, tenaga kerja keluarga perempuan rata-rata 3,31 HOK dan anak-anak rata-rata 1,48 HOK. Intensitas curahan kerja pria lebih besar dalam rumah tangga karena memiliki tanggung jawab yang besar terhadap pemenuhan kebutuhan anggota rumah tangga. Curahan kerja wanita pada usahatani lebih rendah dibandingkan dengan pria karena dalam usahatani padi, wanita hanya membantu kegiatan penanaman dan panen.

\section{Kesimpulan}

Berdasarkan hasil penelitian disimpulkan bahwa sistem pemeliharaan sapi bali di Kecamatan Buke Kabupaten Konawe Selatan lebih dominan sistem pemeliharan semi intensif dengan pola pembibitan. Rata-rata curahan waktu tenaga kerja keluarga pada usaha ternak sapi bali sebesar 0,94 HOK, sedangkan rata-rata curahan waktu tenaga kerja keluarga pada usahatani padi sawah yaitu sebesar 10,56 HOK. Secara umum, tenaga kerja keluarga di Kecamatan Buke Kabupaten Konawe Selatan cukup tersedia namun lebih 


\section{Jurnal Sains Peternakan}

Volume 9 No. 1, Juni 2021, pp:1-6

ISSN 2579-4450

banyak mencurahkan waktunya pada usaha tani padi sawah $(91,83 \%)$ dibandingkan usaha ternak sapi bali $(8,17 \%)$.

\section{Daftar Rujukan}

Abadi, M., Nafiu, L. O., \& Karim, J. (2019). Pemetaan Potensi Sumberdaya Lahan Hijauan Pakan Ternak Sapi Bali di Kecamatan Tinanggea Kabupaten Konawe Selatan. Jurnal Ilmu dan Teknologi Peternakan Tropis, 6(1), 124-137.

Abidin, J., Malesi, L., \& Hadini, H. A. (2018). Motivasi Peternak dalam Pengembangan Usaha Sapi Bali di Kabupaten Muna Barat. Jurnal Ilmu dan Teknologi Peternakan Tropis, 5(2), 17-23.

Fyka, S. A., Limi, M. A., Zani, M., \& Salamah, S. (2019). Analisis Potensi dan Kelayakan Usahatani Sistem Integrasi Padi Ternak (Studi Kasus di Desa Silea Jaya Kecamatan Buke Kabupaten Konawe Selatan). Jurnal Ilmu dan Teknologi Peternakan Tropis, 6(3), 375-381.

Hidayati, F., Yonariza, Y., Nofialdi, N., \& Yuzaria, D. (2020). Analisis Keuntungan dan Kendala Penerapan Konsep Sistem Pertanian Terpadu (SPT) di Indonesia. JIA (Jurnal Ilmiah Agribisnis): Jurnal Agribisnis dan Ilmu Sosial Ekonomi Pertanian, 5(3), 74-83.

Hitani, A. H., Nurliza, N., \& Dolorosa, E. (2017). Analisis Daya Saing Usaha Ternak Sapi Potong Rakyat di Kabupaten Mempawah. Jurnal Social Economic of Agriculture, 6(1), 39-49.

Indrayani, I., \& Andri, A. (2018). Faktor-faktor yang Mempengaruhi Pendapatan Usaha Ternak Sapi potong di Kecamatan Sitiung, Kabupaten Dharmasraya. Jurnal Peternakan Indonesia (Indonesian Journal of Animal Science), 20(3), 151-159.

Kusumayana, P., \& Arlina, A. (2017). Analisis Pendapatan Petani Melalui Sistem Integrasi Tanaman Padi-Ternak Sapi di Desa Jaro Kecamatan Jaro Kabupaten Tabalong (Studi Kasus pada Kelompok Tani “Tani Membangun”). Ziraa'ah Majalah Ilmiah Pertanian, 42(2), 150-157.

Ningrum, N. Z., Limi, M. A., \& Fyka, S. A. (2019). Analisis Multiplier Effect Pengembangan Sistem Mina Padi Bagi Masyarakat Lokal di Desa Epeesi Kecamatan Basala Kabupaten Konawe Selatan. JIA (Jurnal Ilmiah Agribisnis) : Jurnal Agribisnis dan Ilmu Sosial Ekonomi Pertanian, 4(6), 166-172.

Norfahmi F., N Kusnadi, R Nurmalina dan R Winandi. 2017. Analisis Curahan Kerja Rumah Tangga Petani Pada Usahatani Padi dan Dampaknya Terhadap Pendapatan Keluarga. Informatika Pertanian, 26(1) : 13-22.

Sani, L. O. A., Santosa, K. A., \& Ngadiyono, N. (2012). Curahan Tenaga Kerja Keluarga Transmigran dan Lokal pada Pemeliharaan Sapi Potong di Kabupaten Konawe Selatan, Sulawesi Tenggara (Family Labor Allocation of the Transmigrant and Local Farmers for Cattle Raising in Konawe Selatan Regency, Sulawesi Tenggara). Buletin Peternakan, 34(3), 194-201.

Simanjuntak, O. V., Subejo, S., \& Witjaksono, R. (2018). Partisipasi Petani dalam Program Gerakan Penerapan Pengelolaan Tanaman Terpadu Padi di Kecamatan Kalasan Kabupaten Sleman. Agro Ekonomi, 27(1), 20-37. 


\section{Jurnal Sains Peternakan}

Volume 9 No. 1, Juni 2021, pp:1-6

ISSN 2579-4450

Widhyawaty, N. P. (2019). Diversifikasi Hasil Pertanian Terintegrasi dan Pendapatan Petani Peternak di Desa Kerta Kecamatan Payangan Kabupaten Gianyar. Jurnal Manajemen Agribisnis (Journal Of Agribusiness Management), 7(2), 141-146. 